\title{
Pengaruh Media Pembelajaran dalam Proses Pembelajaran Daring terhadap Hasil Belajar Siswa di Era Pandemi Covid-19
}

\author{
1*Adiyati Fathu Roshonah, ${ }^{2}$ Tiara Dwitami \\ 12Universitas Muhammadiyah Jakarta \\ adiyati.1809@gmail.com
}

\begin{abstract}
Abstrak: Abstrak: Penelitian ini bertujuan untuk mengetahui pengaruh penerapan media pembelajaran Power Point melalui aplikasi Google Meet terhadap proses pembelajaran online terhadap hasil belajar siswa kelas IV C di SDN Pisangan 01 Tangerang Selatan. Metode penelitian yang digunakan dalam penelitian ini adalah penelitian kuantitatif dengan metode eksperimen. Desain metode eksperimen yang dipilih dalam penelitian ini adalah True Experimental Design dengan tipe Posttest-Only Control Design. Data diperoleh dengan tes tertulis berupa soal dan dokumentasi. Analisis perhitungan statistik menggunakan uji-t melalui program SPSS 20 for Windows menggunakan Independent Sample T-Test dengan asumsi kedua varians homogen (equal variance asumsi) dengan taraf signifikansi 0,05 . Hasil penelitian ini menunjukkan bahwa Sig. (2-tailed) adalah 0,001 < dari 0,05 yang berarti terdapat perbedaan yang signifikan antara hasil belajar pada kelompok eksperimen dan kelompok kontrol. Penerapan media pembelajaran power point melalui aplikasi google meet lebih unggul daripada diskusi melalui chat room di Grup WhatsApp. Hal ini terlihat dari perolehan nilai rata-rata untuk kelompok eksperimen sebesar 81,8 dan pada kelompok kontrol sebesar 45,3. Perbedaan yang signifikan ini tentunya juga didukung oleh faktor lain seperti peran orang tua dalam membimbing siswa belajar di rumah dan tersedianya fasilitas yang mendukung siswa dalam pembelajaran online.
\end{abstract}

Kata kunci: Media Pembelajaran, Power Point, Google Meet

\begin{abstract}
This study aims to determine the effect of the application of Power Point learning media through the Google Meet application on the online learning process on the learning outcomes of class IV C students at SDN Pisangan 01 Tangerang Selatan. The research method used in this research is quantitative research with experimental methods. The experimental method design chosen in this study is the True Experimental Design with the type of Posttest-Only Control Design. Data obtained by written test in the form of questions and documentation. Statistical calculation analysis uses the t-test through the SPSS 20 for Windows program using the Independent Sample T-Test assuming the two variances are homogeneous (equal variance assumed) with a significance level of 0.05. The results of this study indicate that the Sig. (2-tailed) is 0.001 $<$ from 0.05, which means that there is a significant difference between learning outcomes in the experimental group and the control group. The application of power point learning media through the google meet application is superior to discussion through chat rooms on the WhatsApp Group. This can be seen from the acquisition of an average value for the experimental group of 81.8 and in the control group of 45.3. This significant difference is of course also supported by other factors such as the role of parents in guiding students to study at home and the availability of facilities that support students in online learning.
\end{abstract}

Keywords: Learning Media, Power Point, Google Meet 


\section{Pendahuluan}

Saat ini dunia dilanda pandemi virus Corona atau COVID-19 (Corona Virus Disease 2019). Pada 30 Januari 2020, WHO telah menetapkan kedaruratan kesehatan masyarakat yang meresahkan dunia. Dilansir dari berita harian Detik News, negara Indonesia pertama kali mengkonfirmasikan kasus COVID-19 pada hari Senin 2 Maret 2020 lalu. Saat itu, Presiden Republik Indonesia, Bapak Joko Widodo mengumumkan ada dua warga negara Indonesia yang positif terjangkit virus Corona yakni perempuan berusia 31 tahun dan berusia 64 tahun. Penularan Corona Virus ini sangat mudah melalui kontak dengan sesama manusia sehingga sangat cepat tersebar ke seluruh dunia. Dengan cepatnya penyebaran Corona Virus ini, maka pemerintah mengeluarkan surat edaran pada tanggal 18 Maret 2020 dengan point segala kegiatan di dalam dan di luar ruangan di semua sektor sementara waktu untuk ditunda sementara waktu demi mengurangi penyebaran virus Corona terutama pada bidang pendidikan.

Pada tanggal 24 Maret 2020, Menteri Pendidikan dan Kebudayaan Republik Indonesia mengeluarkan Surat Edaran Nomor 4 Tahun 2020 tentang pelaksanaan kebijakan pendidikan dalam masa darurat penyebaran COVID-19. Dalam Surat Edaran tersebut dijelaskan bahwa proses belajar dilaksanakan di rumah melalui pembelajaran daring (dalam jaringan) atau pembelajaran jarak jauh yang dilaksanakan untuk memberikan pengalaman belajar yang bermakna bagi siswa. Menurut Thome dalam Yanti ${ }^{1}$, pembelajaran daring merupakan pembelajaran yang memanfaatkan teknologi multimedia, video, kelas virtual, teks online animasi, pesan suara, email, telepon, konferensi, dan video streaming online seperti Zoom Meeting, Google Meet, Jitsi, dan sebagainya. Pembelajaran daring merupakan program penyelenggaraan kelas belajar untuk menjangkau kelompok yang masif dan luas melalui jaringan internet. Pembelajaran dapat dilakukan secara masif dengan jumlah peserta yang tidak terbatas, bisa dilakukan secara gratis maupun berbayar. Pembelajaran daring dapat diakses menggunakan internet sehingga menghubungkan pembelajaran dari jarak jauh antara pendidik dan peserta didik.

Pada pembelajaran daring tenaga pendidik harus berinovasi dalam proses pembelajaran yang dapat digunakan untuk mendukung

1 Yanti, Minanti Tirta, et al. (2020). Pemanfaatan Portal Rumah Belajar Kemendikbud Sebagai Model Pembelajaran Daring di Sekolah Dasar. Jurnal Pendidikan Dasar. Fakultas Dharma Acarya Institut Hindu Dharma Negeri Denpasar, 5(1), 61-68. 
pembelajaran jarak jauh. Pemilihan media pembelajaran sangat dibutuhkan dalam proses penyampaian materi sehingga tujuan pembelajaran sampai ke peserta didik. Menurut Wicaksono (2016) menyatakan bahwa peran media sangat penting dalam proses pembelajaran agar materi yang disampaikan oleh guru cepat sampai dan mudah diterima secara maksimal oleh siswa. Dengan demikian salah satu inovasi pembelajaran yang dapat digunakan tanpa harus tatap muka secara langsung yaitu dengan cara memanfaatkan media TIK (Teknologi Informasi Komputer) untuk menunjang pembelajaran secara daring. Media TIK bisa berupa video pembelajaran, macromedia flash, e-book dan media yang lainnya. ${ }^{2}$

Ketersediaan alat komunikasi (handphone atau laptop) yang dimiliki orang tua siswa untuk mengakses media pembelajaran sangatlah beragam. Banyaknya keterbatasan-keterbatasan yang dimiliki membuat peneliti memilih media pembelajaran yang mudah untuk diakses oleh semua siswa. Pada penelitan ini, peneliti hanya menggunakan media pembelajaran berupa Power Point yang dipresentasikan melalui aplikasi Google Meet. Media Power Point adalah sebuah program komputer untuk presentasi yang dikembangkan oleh Microsoft. Dalam media ini terdapat interaksi antara anak dengan media, hal ini akan merangsang rasa ingin tahu anak dan rasa ketertarikan terhadap apa yang dipelajarinya, dengan demikian maksud dari penyuluhan tersebut dapat mencapai hasil yang optimal. ${ }^{3}$

Power Point dengan tema yang berwarna akan membuat siswa memusatkan perhatiannya dengan materi yang disajikan. Presentasi atau menjelaskan materi menggunakan Power Point ini melalui aplikasi Google Meet sebagai treatment untuk kelas eksperimen. Aplikasi Google Meet merupakan salah satu aplikasi dari google yang dapat membantu pembelajaran jarak jauh. Dengan aplikasi google meet ini banyak sekali interaksi pembelajaran yang dapat dilakukan salah satunya adalah men-share screen power point.

Berdasarkan hasil observasi di kelas IV C $\quad$ SDN Pisangan 01 Tangerang Selatan, dalam penyampaian pembelajaranpada pembelajaran Tematik hanya memberi arahan untuk membaca materi yang sudah tersedia di Lembar Kerja Siswa (LKS) dan pada pembelajaran Matematika guru kelas membuat video

2 Sahari, Sutrisno., Wahyudi. (2020). Pengembangan Media Tata Surya Berbasis Macromedia Flash sebagai Inovasi Pembelajaran Daring untuk Siswa SD. Jurnal Pendidikan Dasar Nusantara, 6(1), 174-183.

3 Nurhidayat, Oki, et al. (2012). Perbandingan Media Power Point dengan Flip Chart dalam Meningkatkan Pengetahuan Kesehatan Gigi dan Mulut. Unnes Journal of Public Health, 1(1),31-35. 
cara penyelesaian materi matematika untuk memudahkan siswa mengerjakan tugas yang diberikan serta dapat bertanya melalui WhatsApp Group.

Penelitian ini bertujuan untuk mengetahui pengaruh penerapan media pembelajaran Power Point melalui aplikasi Google Meet pada proses pembelajaran daring terhadap hasil belajar siswa kelas IV C di SDN Pisangan 01 Tangerang Selatan. Dalam hal ini peneliti ingin memberi treatment berbeda dengan menggunakan media pembelajaran Power Point melalui aplikasi Google Meet dalam pembelajaran daring yang diharapkan pembelajaran menjadi lebih aktif sehingga dapat meningkatkan hasil belajar siswa pada kelompok eksperimen.

\section{METODE PENELITIAN}

Metode penelitian yang digunakan dalam penelitian ini adalah Penelitian Kuantitatif dengan metode eksperimen. Metode penelitian kuantitatif ekperimen dapat diartikan sebagai metode penelitian yang digunakan untuk mecari pengaruh perlakuan atau treatment tertentu terhadap yang lain dalam kondisi yang terkendali. Populasi penelitian ini adalah siswa kelas IV C di SDN Pisangan 01 Ciputat Timur Tangerang Selatan semester ganjil pada tahun pelajaran 2020/2021. Sampel yang digunakan dalam penelitian ini sebanyak 20 siswa kelas IV C dengan 10 siswa sebagai kelompok eksperimen dan 10 siswa sebagai kelompok kontrol yang dipilih secara random.

Desain metode eksperimen yang dipilih pada penelitian ini adalah True Experimental Design dengan tipe Posttest-Only Control Design. Dikatakan true experimental karena dalam desain ini peneliti dapat mengontrol semua variabel yang mempengaruhi jalannya eksperimen. Ciri utama dari true experimental design adalah sampel yang digunakan untuk kelompok eksperimen maupun kelompok kontrol diambil secara random dari populasi tertentu. Jadi cirinya adalah adanya kelompok kontrol dan sampel dipilih secara random. Pada tipe posttest-only control design ini terdapat dua kelompok yang masing-masing dipilih secara random (R). Kelompok pertama diberi perlakuan atau treatment (X) dan kelompok yang lain tidak. Kelompok yang diberi perlakuan disebut dengan kelompok eksperimen dan kelompok yang tidak diberi perlakuan disebut sebagai kelompok kontrol (Sugiyono, 2009: 112).

\begin{tabular}{|ccc|}
\hline $\mathrm{R}$ & $\mathrm{X}$ & $\mathrm{O}_{1}$ \\
$\mathrm{R}$ & & $\mathrm{O}_{2}$ \\
\hline
\end{tabular}


Dalam desain metode ini, kelompok eksperimen diberikan perlakuan yakni peneliti mempresentasikan materi menggunakan media pembelajaran Power point melalui aplikasi Google Meet. Sedangkan pada kelompok kontrol, peneliti tidak memberikan perlakuan atau treatment mempresentasikan media pembelajaran Power point. Kedua kelompok diberi tes akhir atau posttest yang sama sebagai alat penilaian untuk mengetahui hasil belajar siswa dari dua kelompok tersebut.

Teknik pengumpulan data berupa tes tertulis dan dokumentasi. Teknik pengumpulan data dalam bentuk tes tertulis dalam penelitian ini menggunakan instrumen tes tertulis yang digunakan untuk mengukur hasil belajar siswa kelas IV C SDN Pisangan 01. Tes ini diberikan kepada siswa melalui WhatsApp Group kelas untuk dikerjakan secara individual. Tes yang digunakan sebanyak enam kali tes tertulis yang diakumulasikan menjadi nilai rata-rata siswa. Pada enam kali tes ini diantaranya tiga tes untuk pelajaran tema 2 (Selalu Berhemat Energi) sub tema 1 (Sumber Energi) dalam bentuk Microsoft Form dan tiga tes lainnya untuk pelajaran matematika dalam bentuk PDF. Tes tertulis ini sebagai posttest yang diberikan kepada kelompok eksperimen dan kelompok kontrol.

Tehnik pengumpulan data berupa dokumentasi digunakan untuk mendapat data sekunder. Dan ini berupa jumlah siswa dan hal-hal yang berkaitan dengan hasil belajar siswa kelas IV C dan proses pembelajaran daring di SDN Pisangan 01 Ciputat Timur Tangerang Selatan. Selanjutnya untuk analisis data penelitian, peneliti menggunakan statistik uji normalitas, uji homogenitas, dan uji beda menggunakan $t$-test. Dalam penghitungan uji statistik, peneliti menggunakan program SPSS 20 for Windows. Dalam penelitian kuantitatif metode eksperimen dengan Posttest Only Control Design ini, pengaruh treatment atau perlakuan dianalisis dengan uji beda seperti statistik $t$-test. Jika terdapat perbedaan yang signifikan antara kelompok ekserimen dengan kelompok kontrol, maka perlakuan yang diberikan berpengaruh secara signifikan ${ }^{4}$.

\section{PEMBAHASAN}

Data yang diperoleh dalam penelitian ini adalah data nilai tes hasil belajar siswa kelas IV C di SDN Pisangan 01 Ciputat Timur Tangerang Selatan.

${ }^{4}$ Sugiyono. (2009). Metode Penelitian Pendidikan Pendekatan Kuantitatif, Kualitatif dan R\&D. Bandung: Penerbit Alfabeta. 
Berikut rekapitulasi hasil belajar siswa kelas IV C berdasarkan kelompok eksperimen dan kelompok kontrol.

Tabel 1

Rekapitulasi Hasil Belajar Siswa Kelas IV C Berdasarkan Kelompok

\begin{tabular}{|c|c|c|}
\hline \multirow{2}{*}{ No } & \multicolumn{2}{|c|}{ Kelompok } \\
\cline { 2 - 3 } & Eksperimen & Kontrol \\
\hline 1 & 96 & 72 \\
\hline 2 & 98 & 0 \\
\hline 4 & 75 & 62 \\
\hline 5 & 63 & 23 \\
\hline 6 & 48 & 33 \\
\hline 7 & 84 & 44 \\
\hline 8 & 83 & 30 \\
\hline 9 & 98 & 70 \\
\hline 10 & 86 & 53 \\
\hline Jumlah & 818 & 66 \\
\hline Rata-rata & $\mathbf{8 1 , 8}$ & $\mathbf{4 5 , 3}$ \\
\hline
\end{tabular}

Sebelum melakukan uji beda menggunakan statistik uji-t, peneliti menguji normalitas dan uji homogenitas pada kelompok. Uji normalitas kelompok eksperimen dan kelompok kontrol dilakukan untuk menentukan apakah data yang diperoleh berdistribusi normal atau tidak. Uji normalitas terhadap dua kelompok tersebut dilakukan dengan uji ShapiroWilk dengan menggunakan SPSS 20 for Windows dengan taraf signifikansi 0,05. Setelah dilakukan pengelolaan data, tampilan output dapat dilihat pada tabel berikut.

Tabel 2

Normalitas Distribusi

\begin{tabular}{|c|l|c|c|c|}
\hline \multirow{2}{*}{} & \multirow{2}{*}{ Kelompok } & \multicolumn{3}{|c|}{ Shapiro-Wilk } \\
\cline { 3 - 5 } & & Stat & df & Sig. \\
\hline Hasil & Eksperimen & .884 & 10 & .143 \\
\cline { 2 - 5 } Belajar & Kontrol & .931 & 10 & .458 \\
\hline
\end{tabular}

Berdasarkan hasil output uji normalitas dengan menggunakan uji Shapiro-Wilk pada Tabel 2 di atas, nilai signifikansi pada kolom Sig. untuk kelompok eksperimen adalah 0,143 dan kelompok kontrol adalah 0,458. Karena nilai signifikansi kedua kelompok lebih dari 0,05, maka dapat dikatakan bahwa kelompok ekspermen dan kelompok kontrol berdistribusi normal. Untuk lebih jelasnya dapat dilihat pada Gambar 1 dan 2. 

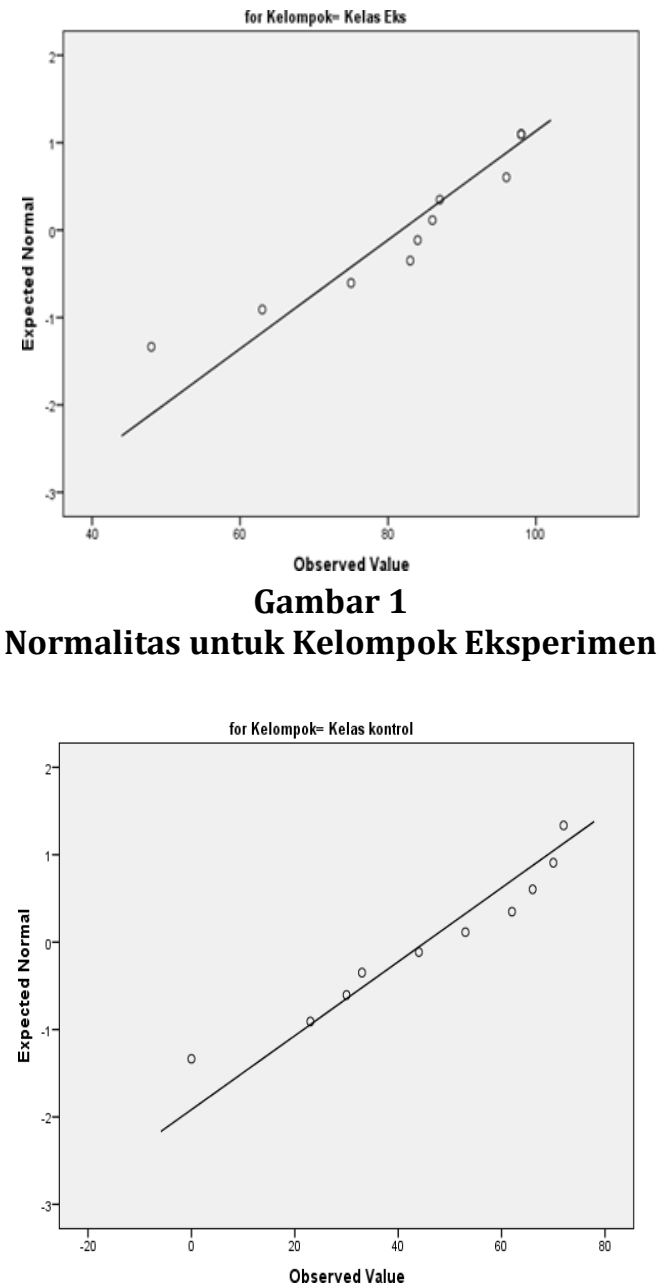

Gambar 2

Normalitas untuk Kelompok Kontrol

Dari grafik diatas terlihat bahwa data tersebar di sekeliling garis lurus. Sehingga dapat disimpulkan bahwa data hasil belajar kelompok eksperimen dan kelompok kontrol berasal dari populasi yang berdistribusi normal.

Berdasarkan uji normalitas distribusi data hasil belajar dua kelompok berdistribusi normal sehingga analisis dilanjutkan dengan menguji homogenitas dua varians antara data kelompok eksperimen dan kelompok kontrol menggunakan uji Levene dengan menggunakan program SPSS 20 for Windows dengan taraf signifikansi 0,05 . Setelah dilakukan pengolahan data, tampilan output dapat dilihat pada Tabel 3

Tabel 3

Homogenitas Dua Varians Hasil Belajar

\begin{tabular}{|l|l|l|l|}
\hline Levene Statistic & df1 & df2 & Sig. \\
\hline 2.243 & 1 & 18 & .152 \\
\hline
\end{tabular}

Al-Manar : Jurnal Komunikasi dan Pendidikan Islam - Volume 10, Nomor 1, Juni 2021 
Berdasarkan hasil output uji homogenitas varians dengan menggunakan uji Levene pada Tabel 3, nilai signifikansinya adalah 0,152. Karena nilai signifikansinya lebih besar dari 0,05, maka dapat disimpulkan bahwa siswa kelompok eksperimen dan kelompok kontrol berasal dari populasi-populasi yang mempunyai varians yang sama, atau kedua kelompok tersebut homogen.

Sebelum melakukan uji-t, kelompok eksperimen dan kelompok kontrol tersebut berdistribusi normal dan memiliki varians yang homogen. Maka selanjutnya dilakukan uji kesamaan dua rerata dengan uji-t melalui program SPSS 20 for Windows menggunakan Independent Sample T-Test dengan asumsi kedua varians homogen (equal varians assumed) dengan taraf signifikansi 0,05. Dasar pengambilan keputusan pada uji independent sampel T-test sebagai berikut:

a. Jika nilai Sig. (2-tailed) $<0,05$ maka terdapat perbedaan yang signifikan antara hasil belajar kelompok eksperimen dengan kelompok kontrol.

b. Jika nilai Sig. (2-tailed) >0,05 maka tidak terdapat perbedaan yang signifikan antara hasil belajar kelompok eksperimen dengan kelompok kontrol. Setelah dilakukan pengelolaan data, tampilan hasil uji t-test dapat dilihat pada Tabel 4.

\begin{tabular}{|l|l|l|c|c|c|}
\hline \multirow{2}{*}{} & Kelompok & $\mathrm{N}$ & Mean & $\begin{array}{c}\text { Std. } \\
\text { Deviation }\end{array}$ & $\begin{array}{c}\text { Std. Error } \\
\text { Mean }\end{array}$ \\
\cline { 2 - 6 } $\begin{array}{l}\text { Hasil } \\
\text { Belajar }\end{array}$ & Eksperimen & 10 & 81,8000 & 16.05408 & 5.07674 \\
\cline { 2 - 6 } & Kontrol & 10 & 45,3000 & 23.63166 & 7.47299 \\
\hline
\end{tabular}

Dari tabel diatas, sampel (n) kelompok eksperimen dan kelompok kontrol sama-sama berjumlah 10 siswa yang dipilih secara random. Rata-rata hasil belajar pada kelompok eksperimen adalah 81,8 sedangkan pada kelompok kontrol sebesar 45,3. Setelah mengetahui nilai rata-rata, maka kita dapat menentukan nilai signifikansi. Output sebagaimana pada Tabel 5. 
Tabel 5. Independent Sampel Test

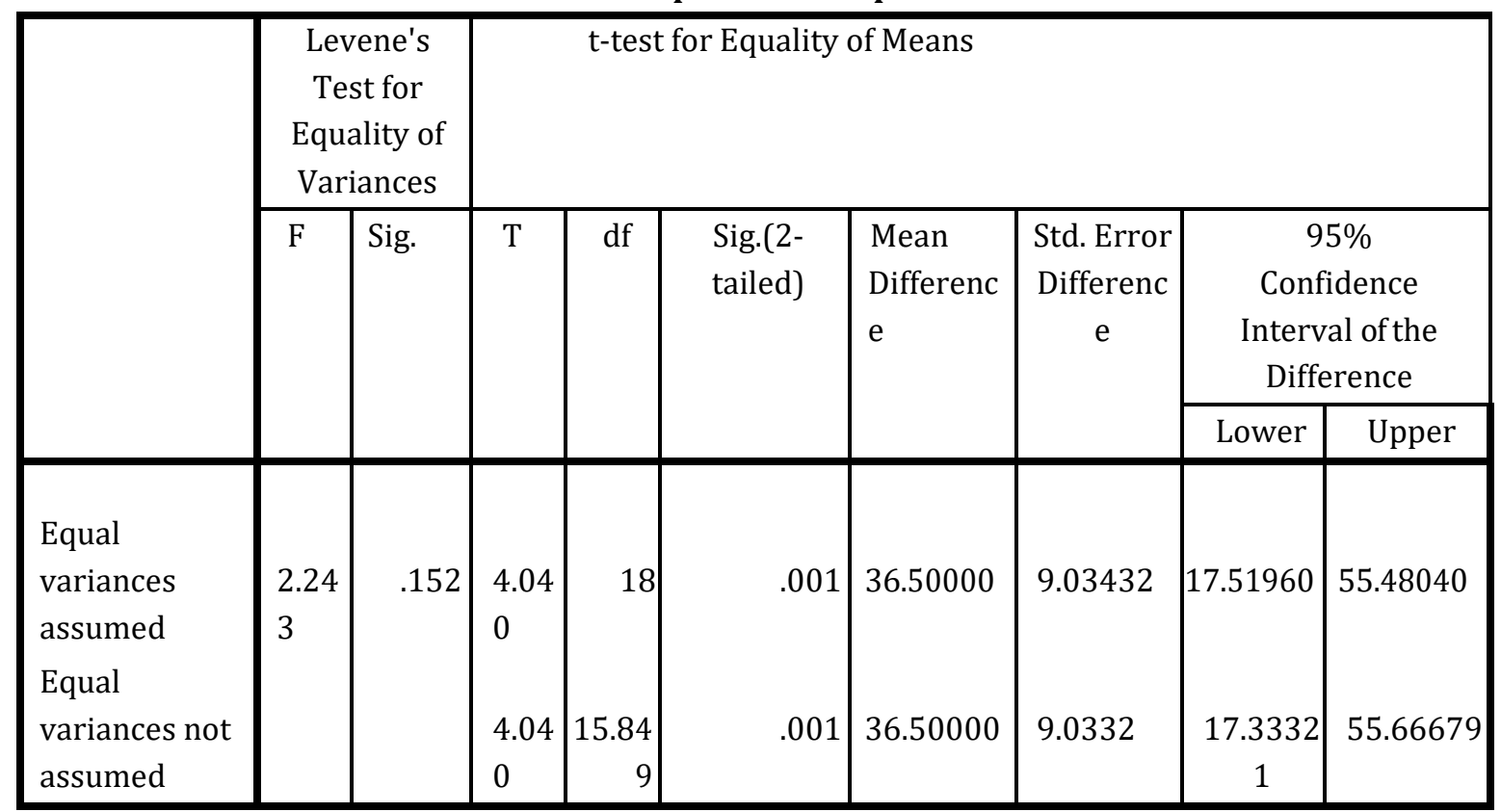

Dari hasil output tabel diatas, equal variances assumed dengan Sig.(2tailed) sebesar 0,001. Maka dapat disimpulkan bahwa Sig.(2-tailed) yaitu $0,001<$ dari 0,05 yang artinya terdapat perbedaan yang signifikan antara hasil belajar pada kelompok eksperimen dengan kelompok kontrol.

Berdasarkan hasil hitung uji ststistik menggunakan uji independent sample T-test, dapat diketahui bahwa penerapan media pembelajaran power point melalui aplikasi google meet dengan yang tidak melalui aplikasi google meet terhadap hasil belajar siswa kelas IV C di SDN Pisangan 01 Tangerang Selatan menunjukkan perbedaan yang signifikan. Hal ini didasari atas uji independent sampel T-test yang menunjukkan bahwa Sig.(2-tailed) yaitu $0,001<$ dari 0,05 yang artinya terdapat perbedaan yang signifikan antara hasil belajar pada kelompok eksperimen dengan kelompok kontrol.

Kemampuan siswa dalam memahami materi pembelajaran yang dikemas dalam bentuk media power point dan dijelaskan melalui aplikasi google meet serta belajar dengan cara bertatap muka walaupun secara virtual lebih berpengaruh dibandingkan dengan hanya membagikan materi berupa power point di WhatsApp Group. Hal ini dapat dilihat dari perolehan nilai rata-rata siswa pada kelompok eksperimen dan kelompok kontrol berbeda. Perolehan nilai rata-rata kelompok eksperimen sebesar 81,8 dan kelompok kontrol sebesar 45,3. Pada nilai rata-rata hasil belajar siswa di setiap kelompok sudah menggambarkan perbedaan yang cukup jelas. 
Disamping keberhasilan hasil belajar siswa, pada proses pembelajaran daring ini peran orang tua sangat penting untuk mendampingi anak.

Proses kegiatan belajar-mengajar dilakukan secara daring menuntut keikutsertaan orang tua didalam proses pembelajaran siswa. Menurut Nurlaeni \& Juniarti (2017) dalam Lilawati ${ }^{5}$, orangtua pada awalnya berperan dalam membimbing sikap serta keterampilan yang mendasar, seperti pendidikan agama untuk patuh terhadap aturan, dan untuk pembiasaan yang baik, namun perannya menjadi meluas yaitu sebagai pendamping pendidikan akademik. Mengingat pentingnya peranan orang tua dalam mendidik anak, penelitian - penelitian yang ada telah membuktikan bahwa orang tua memiliki andil yang sangat besar dalam kemampuan anak dalam lingkup pendidikan. Peran orang tua dalam menentukan prestasi belajar siswa sangatlah besar. Orang tua yang tidak memperhatikan pendidikan anaknya dapat menyebabkan anak kurang atau bahkan tidak berhasil dalam belajarnya. Sebaliknya, orang tua yang selalu memberi perhatian pada anaknya, terutama perhatian pada kegiatan belajar mereka di rumah, akan membuat anak lebih giat dan lebih bersemangat dalam belajar karena ia tahu bahwa bukan dirinya sendiri saja yang berkeinginan untuk maju, akan tetapi orang tuanya juga memiliki keinginan yang sama. Sehingga hasil belajar atau prestasi belajar yang diraih oleh siswa menjadi lebih baik ${ }^{6}$.

Selain peran orangtua, ketersediaan alat-alat elektronik yang memadai seperti handphone dan laptop menjadi alat untuk mengikuti pembelajarn daring. Dalam kasus di kelas IV C SDN Pisangan 01 Tangerang Selatan, masih ada beberapa orang tua yang tidak dapat memfasilitasi alat untuk siswa mengikuti pembelajaran daring. Saat proses kegiatan pembelajaran daring, masih terdapat orang tua yang izin untuk tidak mengikuti pembelajaran daring dengan alasan handphone akan dibawa orang tua bekerja, tidak bisa mengakses aplikasi google meet, dan alasan lainnya. Disamping itu, masih ada beberapa siswa yang mengumpulkan tugas melebihi waktu yang ditentukan bahkan ada beberapa siswa yang tidak mengerjakan tugas-tugasnya sama sekali.

Adapun keterbatasan dalam penelitian ini yaitu keterbatasan waktu penelitian, kegiatan belajar-mengajar dilakukan secara online sehingga sulit untuk mengontrol hasil belajar siswa apakah dikerjakan individu yang bersangkutan atau orangtua yang mengerjakan, keterbatasan dalam fasilitas yang dimiliki oleh orang

5 Lilawati, Agustien. (2020). Peran Orang Tua dalam Mendukung Kegiatan Pembelajaran di Rumah pada Masa Pandemi. Jurnal Pendidikan Anak Usia Dini, 5(1), 549-558.

${ }^{6}$ Haerudin., et al. (2020). Peran Orang Tua dalam Membimbing Anak Selama Pembelajaran di Rumah sebagai Upaya Memutuskan Covid-19. Universitas Singaperbangsa Karawang, 1-12

Al-Manar : Jurnal Komunikasi dan Pendidikan Islam - Volume 10, Nomor 1, Juni 2021 
tua sehingga siswa tidak dapat mengikuti pembelajaran, serta sampel penelitian yang sedikit.

\section{KESIMPULAN}

Berdasarkan pembahasan hasil penelitian, dapat disimpulkan bahwa perbedaan penerapan media pembelajaran Power Point melalui aplikasi Google Meet dengan room chat di WhatsApp Group terhadap hasil belajar siswa kelas IV C di SDN Pisangan 01 Tangerang Selatan memiliki perbedaan pengaruh yang signifikan. Hal ini dapat dilihat dari uji Independent Sample T-Test dengan asumsi kedua varians homogen (equal varians assumed) dengan taraf signifikansi 0,05. Dari hasil uji t-test, equal variances assumed dengan Sig.(2-tailed) yaitu 0,001 < dari 0,05 yang artinya terdapat perbedaan yang signifikan antara hasil belajar pada kelompok eksperimen dengan kelompok kontrol.

Penerapan media pembelajaran power point melalui aplikasi google meet lebih unggul dibandingkan dengan berdiskusi melalui room chat di WhatsApp Group. Hal ini dapat dilihat dari hasil perolehan nilai ratarata siswa di setiap kelompok. Pada kelompokeksperimen nilai rata-rata hasil belajar siswa sebesar 81,8 sedangkan padakelompok kontrol nilai rata-rata hasil belajar siswa sebesar 45,3. Perbedaan yang signifikan ini tentunya juga didukung oleh faktor-faktor lain seperti peran orang tua dalam membimbing siswa belajar di rumah, ketersediaannya fasilitas yang mendukung siswa dalam pembelajaran daring, tingkatan kognitif siswa, dan karakteristik siswa.

\section{DAFTAR PUSTAKA}

Haerudin., et al. (2020). Peran Orang Tua dalam Membimbing Anak Selama Pembelajaran di Rumah sebagai Upaya Memutuskan Covid-19. Universitas Singaperbangsa Karawang, 1-12

Lilawati, Agustien. (2020). Peran Orang Tua dalam Mendukung Kegiatan Pembelajaran di Rumah pada Masa Pandemi. Jurnal Pendidikan Anak Usia Dini, 5(1), 549-558.

Nurhidayat, Oki, et al. (2012). Perbandingan Media Power Point dengan Flip Chart dalam Meningkatkan Pengetahuan Kesehatan Gigi dan Mulut. Unnes Journal of Public Health, 1(1),31-35.

Sahari, Sutrisno., Wahyudi. (2020). Pengembangan Media Tata Surya Berbasis Macromedia Flash sebagai Inovasi Pembelajaran Daring untuk Siswa SD. Jurnal Pendidikan Dasar Nusantara, 6(1), 174-183. 
Sugiyono. (2009). Metode Penelitian Pendidikan Pendekatan Kuantitatif, Kualitatif dan R\&D. Bandung: Penerbit Alfabeta.

Yanti, Minanti Tirta, et al. (2020). Pemanfaatan Portal Rumah Belajar Kemendikbud Sebagai Model Pembelajaran Daring di Sekolah Dasar. Jurnal Pendidikan Dasar. Fakultas Dharma Acarya Institut Hindu Dharma Negeri Denpasar, 5(1), 61-68. 